\title{
Rrocess Machinery and Equipment ${ }^{*}$
}

\author{
Isaburo Watanabe**
}

\section{Engineering}

In order to cope with the rapid development of the mining and other industries by the national income doubling plan of the Ikeda Cabinet and also to provide for the wide range liberalization of international trade in 1962, most petroleum and petrochemical companies rapidly increased their capital expenditure plan. This far expanded plant investment plan has been, however, greatly affected by the rapid growth of economics, the recent worsening of the balance of the foreign trade and the tight money policy of the government. In the field of the petroleum industry only, the original total investment plan in 1962 amounted to 137.8 billion yen was reduced to 82.6 billion yen at the government's suggestion. This is a ten percent reduction over the total investment in 1961.

Engineering companies have also expanded their activities so as to meet the increased investment by the petroleum and petrochemical companies, but the amount of job orders that they receive from the petroleum and petrochemical companies have been undoubtedly decreasing by the aforementioned reduction in investment. Large engineering companies still had sufficient jobs for one more year as of the end of 1962, however.

The status of engineering companies in Japan has been discussed in Volumes 3 and 4 of the "Bulletin of Japan Petroleum Institute". The leading engineering companies such as the Japan Gasoline Company and Chiyoda Chemical Engineering and Construction Company have since made their footing more secure and, on the other hand, large process machinery and equipment manufacturers such as shipbuilding companies are strengthening their engineering departments. It is the recent tendency, moreover, that these manufacturing companies separate their engineering depart-

* Received January 26, 1963.

** Japan Gasoline Co., Ltd. departments to form new engineering companies. For example, Fujinagata Engineering Company, born in October of 1962, was an engineering department of Fujinagata Shipbuilding Company. The major chemical companies are also separating their engineering departments to form engineering companies. For example, Toyo Engineering Company, originated in 1961 from the engineering department of Toyo Koatsu Industries Inc., is now entering into the domestic and overseas market for the engineering of the urea plant. In July of 1962, Toyo Engineering Company announced the technical tie up with the Lummus Company in the United States.

Overseas contracts for the plant construction has been also increased. With this move, engineering is playing a great part in exporting heavy machinery and equipment. The total amount of the contracts out of Japan in 1962 is approximated at 100 million dollars which includes the contracts of a paper manufacturing plant by the Shin Mitsubishi Heavy Industry Company and $\mathrm{Mi}$ tsubishi Shipbuilding Company for USSR and Malaya, and a rayon plant by Mitsubishi \& Company for Pakistan. Included in these contracts are basic design, detailed design, construction of the plants and operational supervision. Therefore, in many cases, process machinery and equipment manufacturers and engineering companies are very closely cooperated in securing the overseas contracts since all-around high technique is required by the contractors. To further promote the overseas activities of the engineering companies, several survey groups recently visited foreign countries. In September of 1962, an inspection delegation sponsored by the Japan Society of Industrial Machinery Manufacturers and the Association for the Promotion of International Trade was sent to Russia to inspect the petroleum and chemical facilities in the USSR. This delegation, headed by Mr. Akiyoshi Tamaki, president of Chiyoda Chemical Engineering and Construction Company, consisted of 13 
men from various engineering companies and process machinery and equipment manufacturing companies. They made a 3 week tour of Russia to see Russian petroleum and petrochemical facilities.

\section{Manufacturing of Process Machinery and Equipment}

Japan has a fairly long history of development in the process machinery and equipment manufacturing field. Owing greatly to their constant efforts and the result of technical cooperation with overseas advanced companies, the performance of the domestic machinery and equipment has now reached the international level. This will be understood from the fact that most materials needed for construction of modern petroleum and chemical plants are now produced in Japan.

The national income doubling plan requests that the total manufacturing capacity of the process machinery and equipment in 1970 be five times over that in 1960 . The overseas activities, particularly in Asian countries, are expected to become more promising. The following is the present status of some of the process machinery nad equipment manufactures in Japan.

(1) Compressors:

Reciprocating type compressors, one of the high pressure compressors for hydrogen gas, had already been fabricated in Japan before the Pacific War. However, many hydrogen gas compressors for naphtha reforming units and hydrogen treating units of naphtha, kerosene, and gas oil which were installed in Japan after the end of the war, had been from time to time imported because of the operational reliability. That is, until domestic production was initiated in 1960 by the technical tie up with foreign manufacturers. Quite recently, domestic production of multistage centrifugal type compressors was also started. The Nippon Petroleum Refining Company has employed this type compressor manuactured by the Shin Mitsubishi Heavy Industry Company for the Platforming Unit at their Kudamatsu Refinery. Maruzen Oil Company and Idemitsu Kosan Company and Nichimo Sekiyu Seisei K.K. also plan to use a centrifugal compressor of 2,000-3,000 HP now under manufacture by the Shin Mitsubishi Heavy Industry Company, Mitsubishi Shipbuilding Company and Mitsui Shipbuilding Company for the Platforming Units which are scheduled to go on stream very soon.

(2) High Pressure Vessels:

The Japanese petroleum refining and petrochemical plants are reaching the international level in their capacity and performance. All kinds of the high pressure vessels are now being manufactured in Japan. Of these, alloy and clad steel reactors are discussed in Volumes 1, 3 of the Bulletin of Japan Petroleum Institute. An unusually large hydrocracking unit is presently being installed here in Japan. A large reactor of three meters in diameter and twenty five meters in length under $140 \mathrm{~kg} / \mathrm{cm}^{2}$ or more of pressure is required for such a unit. Therefore, more improvement is strongly desired in this field in Japan.

Shinko-Smith Co., established in April of 1961 by a joint venture of Kobe Steel Works, Ltd. and O. A. Smith International in the United States, conducted a breaking test on the trial multilayer high pressure vessel in July of 1962 which they manufactured and are reported to start the commercial production of this type high pressure vessels. Shin Mitsubishi Heavy Industry Company recently entered into a technical assistance agreement with Badische Anilin und Soda Fabrik to manufacture multistage high pressure vessels, too.

(3) Heat Exchangers:

With the rapid increase of the plant installations, the supply of industrial water is getting to be quite a problem in Japan. In some districts, air cooling systems have been employed for petroleum refining and petrochemical plants and unexceptionally keen attention is now being given to the air cooling system. Major engineering companies are entering into technical assistance agreements with overseas manufacturers to meet the domestic demand for air coolers. Chiyoda Chemical Engineering and Construction Company has entered a technical assistance agreement with the Hudson Engineering Corp. of the United States and the Yokoyama Engineering Company with the Gea Luft Kühler GmbH of West Germany. Negotiations have been reportedly conducted between the Fujinagata Engineering Company and the Yuba Heat Transfer Corp. of the United States concerning technical cooperation. The Yokoyama Engineering Company have reportedly completed a heat exchanger manufacturing plant and the first product has recently made its debut. Besides these companies, fin tube type heat exchangers, 
now commercially manufactured in Japan through a technical tie up between the Japan Gasoline Company and the Brown Fintube Company of the United States, have been widely accepted here.

(4) Storage Tanks:

With the rapid progress of the petroleum industry, demand for storage facilities has also been considerably increased. Crude tanks having capacities of more than 50,000 KI have been installed in the various locations. Introduction of technical know-how on the floating roof tank has been successfully made. Application to the Government has also been made by the Shin Mitsubishi Heavy Industry Company to introduce a technique of the Power Gas Company of the
United States, the Mitsui Shipbuilding Company and the Nooter Corporation of the United States.

In this field, Toyo Kanetsu K.K. have already entered into an agreement with the Pittsburgh Des Moines Steel Company of the United States; Ishii Iron Works, Ltd. with the Graver Tank and Manufacturing Corp. of the United States; Ishikawajima Harima Heavy Industries Company with the Chicago Bridge and Iron Company of the United States, Nagoya Shipbuilding Company with the Wyatt Industries Inc. of the United States. Chiyoda Chemical Engineering and Construction Company have developed their own technique for the floating roof tank. 